\title{
The Chemical and Nutritional Properties of Processed Fruit Enriched with Algae
}

\author{
Somayeh Ranjbar-Shamsi $\left(\mathbb{D},{ }^{1}\right.$ Anousheh Sharifan $\mathbb{D}^{1},{ }^{1}$ \\ Mozhgan Emtyazjoo, ${ }^{2}$ and Maryam Moslehishad $\mathbb{1}^{3}$ \\ ${ }^{1}$ Department of Food Science and Technology, Science and Research Branch, Islamic Azad University, Tehran, Iran \\ ${ }^{2}$ Department of Marine Science and Technology, North Tehran Branch, Islamic Azad University, Tehran, Iran \\ ${ }^{3}$ Department of Food Science and Technology, Safadasht Branch, Islamic Azad University, Tehran, Iran
}

Correspondence should be addressed to Anousheh Sharifan; a_sharifan2000@yahoo.com

Received 29 April 2021; Revised 22 July 2021; Accepted 18 October 2021; Published 20 December 2021

Academic Editor: Fabio Napolitano

Copyright (c) 2021 Somayeh Ranjbar-Shamsi et al. This is an open access article distributed under the Creative Commons Attribution License, which permits unrestricted use, distribution, and reproduction in any medium, provided the original work is properly cited.

\begin{abstract}
Currently, processed fruits (sour fruit and fruit paste) are consumed as one of the most popular goodies in the some countries, and the position of this product in the food basket of Iranian families is gradually becoming important. Algae are an excellent potential source of natural compounds that can be used as a functional food. The aim of this study was to investigate the effect of Sargassum ilicifolium, Ulva lactuca, and Gracilaria cortica algae at different concentrations (1.5 and 3\%) on the chemical and nutritional properties of processed fruit formulations. Fatty acid profiles were measured by gas chromatography. Vitamin contents were measured using HPLC. Inductively coupled plasma (ICP) was used to measure minerals. In the fatty acid profile, 21 fatty acids including saturated fatty acids, unsaturated fatty acids, and PUFAs were identified. The predominant fatty acids in samples were palmitic acid, stearic acid, oleic acid, and linoleic acid. E and B1 vitamins varied from 6.19 to $22.63 \mathrm{mg} / \mathrm{g}$ and $5.38-19.10 \mathrm{mg} / \mathrm{g}$ in sour fruits and fruit paste, respectively. Among the minerals, iodine was at the highest level in all samples $(5.06-607.46 \mathrm{mg} / \mathrm{g}) . \mathrm{In}$ conclusion, these seaweeds can be used as a suitable source of fatty acids, minerals, and vitamins in the formulation of functional processed fruits, which are essential for human health.
\end{abstract}

\section{Introduction}

The functional foods have been developed to promote health and reduce diseases. To meet consumer demand as well as comply with global laws and regulations, researchers are trying to combine the functional bioactive elements derived from fruits, vegetables, grains, herbs and spices, and macro- and microalgae $[1,2]$. Bioactive ingredients naturally present in plants include protein, minerals, vitamins, fatty acids (especially essential fatty acids), dietary fiber, and carotenoids [3].

Algae are a rich source of many essential bioactive substances, including antioxidants, minerals, amino acids, and essential fatty acids. In addition, higher levels of soluble dietary fiber make them a potential source for functional foods [4].
Around the world, 8 million tons of seaweed are collected annually, most of which are dedicated to algae that are dumped on the beach. On the southern coast of Iran, algae dumped on the shores of the Oman Sea coast, mainly of the species Sargassum ilicifolium, Ulva lactuca, and Gracilaria cortica, reach about 2000 tons per year [5]. These marine plants can be used as an alternative to some food and feed compounds and can also be placed directly in the food basket of consumers. In most cases, seaweed is consumed in food or feed due to its vitamin and mineral contents or polysaccharides. However, the biological value of seaweed protein is not clearly articulated. [6,7].

Studies have demonstrated the applications of various algae, i.e., micro- and macroalgae, to fortification of functional foods, including yogurt [8], snack [9], pasta [10], cake [11-13], grain products such as bread, cupcake, and cookie 
[14], croissants [15], strudel [16], refrigerated hake [17], and rainbow trout $[18,19]$.

The algae can be a rich source in food formulation, such as processed fruits. Processed fruits are produced from the various dried or fresh fruits. In this processing, the fruits are packaged and presented after separation, washing, and adding optional ingredients including salt, sugar, and citric acid, with or without the cooking process. These products are also used as seasonings in various foods $[20,21]$.

The aim of this study is to produce functional processed fruits using the Ulva lactuca, Sargassum ilicifolium, and Gracylaria cortica algae. Identifying nutrient compounds such as fatty acid profiles, vitamins, and minerals in these products can help assess the potential of different species for use in the food industry.

\section{Materials and Methods}

2.1. Materials. The algae powder of S. ilicifolium, U. lactuca, and G. cortica was purchased from Algae Development Company (Fars, Iran). A sampling of the algae was performed from March to April 2019, where the algae grow in the rocky areas of Chabahar Province, Iran [6].

2.2. Preparation of the Product. The formulation of processed fruits enriched with S. ilicifolium, U. lactuca, and G. cortica algae is shown in Tables 1 and 2. For preparation of processed fruits, the fruits after washing are crushed and then be precooked. The fruit puree is pumped through steel pipes to large tanks for cooking. To maintain the quality, flavor, and color of the product, the thermal processing has been carried out at $60^{\circ} \mathrm{C}$ and 26-inch $\mathrm{Hg}$. Then, salt and citric acid and other additives (including algae powder) are added to create to the final product.

\subsection{Experiments}

2.3.1. Lipid Extraction and Fatty Acid Analysis. The extracted algae oil was obtained by solvent extraction. The fatty acids were converted to fatty acid methyl esters (FAMEs). CG analyses of the FAMEs were carried out on a Younglin 6100 gas chromatograph equipped with an FID detector $(30 \mathrm{~m} \times 32 \mathrm{~mm} \times 25 \mu \mathrm{m})$. Hydrogen gas was used as a carrier gas with a purity of $99.99 \%$. The detector and injector temperatures were set to 300 and $280^{\circ} \mathrm{C}$, respectively. The oven temperature was initially set at $160^{\circ} \mathrm{C}$ for $4 \mathrm{~min}$ and elevated to $255^{\circ} \mathrm{C}$. The gas flow rate was $2 \mu \mathrm{L} / \mathrm{min}$ $[22,23]$.

2.3.2. Vitamin Analysis. The samples ( $50 \mathrm{~g})$ were mashed in a homogenizer, and 1-2 $\mathrm{g}$ of homogenate sample was taken for extraction of vitamins $\mathrm{A}, \mathrm{E}$, and $\mathrm{C}$. To the abovementioned homogenates, $4 \mathrm{ml}$ of ethanol was added, vortexed, and centrifuged at $2000 \mathrm{rpm}$ for $3 \mathrm{~min}$ at $4^{\circ} \mathrm{C}$. The supernatant was also filtered through Whatman No. 1 paper, and to the filtrate $0.15 \mathrm{ml}, \mathrm{n}$-hexane was added and mixed. Vitamins A and E were extracted twice in the hexane phase, and the extract was dried under a stream of liquid nitrogen.
Five microliter aliquots of samples were injected manually into HPLC $\left(4.6 \mathrm{~mm} \times 150 \mathrm{~mm} \times 5 \mu \mathrm{m}\right.$, LiChrosorb ${ }^{\circledR}$ Si60: C18, made in USA) equipped with an ultraviolet (UV) spectrophotometric detector with a methanol:acetonitrile: chloroform $(47: 42: 11, \mathrm{v} / \mathrm{v})$ mobile phase at $1 \mathrm{ml} / \mathrm{min}$ flow rate. For extraction of vitamin $\mathrm{C}, 1 \mathrm{~g}$ homogenized sample and $1 \mathrm{ml}$ of $0.5 \mathrm{M}$ perchloric acid were added and vortexed, and the volume was adjusted to $5 \mathrm{~mL}$ by adding $\mathrm{H}_{2} \mathrm{O}$. The mixture was centrifuged at $5000 \mathrm{rpm}$ for $8 \mathrm{~min}$ at $4^{\circ} \mathrm{C}$. The supernatant was filtered, as earlier, and the vitamin $\mathrm{C}$ was determined using HPLC, utilizing a column $(250 \times 3.9$ i.d. $)$ packed with $\mathrm{C} 18$ reversed-phase material with the mobile phase (3.7 mM phosphate buffer, $\mathrm{pH} 4.0$ ) at $1 \mathrm{~mL} \mathrm{~min}^{-1}$ flow rate [24].

For analyzing of riboflavin $\left(\mathrm{B}_{2}\right), 0.3 \mathrm{~g}$ of sample was extracted with $15 \mathrm{~mL}$ hydrochloric acid in a boiling water bath for $60 \mathrm{~min}$. After cooling, the $\mathrm{pH}$ was adjusted to 4.5 with sodium acetate followed by incubation $\left(37^{\circ} \mathrm{C} ; 24 \mathrm{~h}\right)$. The final volume of the extract $(25 \mathrm{~mL})$ was obtained with weak acetic acid $(0.02 \mathrm{M})$, and the filtered extract $(0.2 \mu \mathrm{m})$ was analyzed on a C18 column $(2.1 \mathrm{~mm} \times 100 \mathrm{~mm} \times 1.7 \mu \mathrm{m})$ with an FLR detector at wavelengths of $444 \mathrm{~nm}$ (excitation) and $520 \mathrm{~nm}$ (emission). The separation was achieved with a linear gradient of $20 \mathrm{mM}$ ammonium acetate dissolved in $30 \%$ aqueous methanol at a constant flow of $0.2 \mathrm{~mL} / \mathrm{min}$ at $30^{\circ} \mathrm{C}$. Each extract was injected twice $(10-15 \mu \mathrm{L})$. Quantification was based on an external standard method using a multilevel standard curve of riboflavin $(0.01-1.0 \mathrm{ng} / \mu \mathrm{L})$.

2.3.3. Mineral Analysis. Inductively coupled plasma (ICP, Perkin-Elmer; model Optima ${ }^{\mathrm{TM}} 8000$ DV, USA) was used for measurements of minerals. First, the microwaving digestion method was used using closed containers made of PTFE or quartz. The heat source is microwaves, and the reaction is performed by controlling temperature and pressure. Usually, 0.1 to $1 \mathrm{~g}$ sample is digested with 2 to $10 \mathrm{ml}$ of dilute nitric acid in 15 to 60 minutes and injected directly into the plasma flame, and the emission of each element at a specific wavelength was measured after background correction $[25,26]$.

2.4. Statistical Analysis. The experimental results were statistically analyzed using the SPSS statistical package (version 20, SPSS Inc., Woking, Surrey, UK). An ANOVA was performed to determine the statistical significance of the samples $(p<0.05)$. The results were expressed as mean value \pm standard deviation of three replications.

\section{Results and Discussion}

3.1. Fatty Acid Profile. The fatty acid profile of functional processed fruit containing $3 \%$ and $1.5 \%$ S. ilicifolium, U. lactuca, and G. cortica algae is shown in Tables 3-6.

In this study, 21 different fatty acids including saturated, unsaturated, and polyunsaturated fatty acids (PUFAs) were identified. The predominant fatty acids in sour fruits were palmitic acid (C16:0), oleic acid (C18:1), and linoleic acid $(\mathrm{C} 18: 2)$, and the major fatty acids in functional fruit paste 
TABLE 1: Ingredients used in the main formulation of processed fruits.

\begin{tabular}{lcc}
\hline Product & Ingredients & $\%$ \\
\hline & Date & 71 \\
Sour fruits & Refined salt & 3 \\
& Citric acid & 1 \\
& Water & 25.7 \\
\hline & Apple & 81 \\
Fruit paste & Refined edible salt & 1.8 \\
& Citric acid & 1 \\
& Sugar & 1 \\
& Water & 15.2 \\
\hline
\end{tabular}

TABLE 2: The studied treatments [16].

\begin{tabular}{|c|c|c|c|}
\hline Treatments & $\begin{array}{c}S . \\
\text { ilicifolium }\end{array}$ & $\begin{array}{c}U . \\
\text { lactuca }\end{array}$ & $\begin{array}{c}G . \\
\text { cortica }\end{array}$ \\
\hline $\mathrm{F}_{0}$ control (sour fruits) & 0 & 0 & 0 \\
\hline $\mathrm{FS}_{1}$ & 1.5 & - & - \\
\hline $\mathrm{FG}_{1}$ & - & 1.5 & - \\
\hline $\mathrm{FU}_{1}$ & - & - & 1.5 \\
\hline $\mathrm{FS}_{2}$ & 3 & - & - \\
\hline $\mathrm{FG}_{2}$ & - & 3 & \\
\hline $\mathrm{FU}_{2}$ & - & - & 3 \\
\hline $\mathrm{L}_{0}$ control (fruit paste) & 0 & 0 & 0 \\
\hline $\mathrm{LS}_{3}$ & 1.5 & - & - \\
\hline $\mathrm{LG}_{3}$ & - & 1.5 & \\
\hline $\mathrm{LU}_{3}$ & - & - & 1.5 \\
\hline $\mathrm{LS}_{4}$ & 3 & - & - \\
\hline $\mathrm{LG}_{4}$ & - & 3 & - \\
\hline $\mathrm{LU}_{4}$ & - & - & 3 \\
\hline
\end{tabular}

TABLe 3: Fatty acid profile of sour fruit samples with $3 \%$ algae powder.

\begin{tabular}{|c|c|c|c|c|}
\hline Fatty acids & $\mathrm{FS}_{2}$ & $\mathrm{FG}_{2}$ & $\mathrm{FU}_{2}$ & $\mathrm{~F}_{0}$ \\
\hline C12:0 & $1.01 \pm 0 / 30^{\mathrm{a}}$ & $0.55 \pm 00.07^{\mathrm{b}}$ & $1.01 \pm 0.30^{\mathrm{b}}$ & $0.68 \pm 0.04^{\mathrm{ab}}$ \\
\hline $\mathrm{C} 14: 0$ & $1.41 \pm 0.26^{\mathrm{b}}$ & $1.34 \pm 0.11^{\mathrm{b}}$ & $1.94 \pm 0.05^{\mathrm{a}}$ & $1.29 \pm 0.29^{\mathrm{b}}$ \\
\hline $\mathrm{C} 16: 0$ & $23.78 \pm 0.38^{b}$ & $27.01 \pm 1.12^{\mathrm{a}}$ & $25.86 \pm 1.04^{\mathrm{ab}}$ & $25.61 \pm 0.72^{\mathrm{ab}}$ \\
\hline $\mathrm{C} 16: 1$ & $4.66 \pm 0.64^{\mathrm{a}}$ & $5 / 67 \pm 63 / 0 / 63^{a}$ & $0.21 \pm 0.01^{\mathrm{b}}$ & $1.15 \pm 0.007^{\mathrm{b}}$ \\
\hline $\mathrm{C} 17: 0$ & $2.20 \pm 0.02^{\mathrm{ab}}$ & $0.38 \pm 0.02^{\mathrm{b}}$ & $1.28 \pm 0.09^{\mathrm{a}}$ & $1.13 \pm 0.02^{\mathrm{a}}$ \\
\hline $\mathrm{C} 17: 1$ & $0.36 \pm 0.08^{\mathrm{a}}$ & $0.22 \pm 0.01^{\mathrm{b}}$ & $0.10 \pm 0.01^{\mathrm{b}}$ & $0.11 \pm 0.007^{\mathrm{b}}$ \\
\hline $\mathrm{C} 18: 0$ & $3.89 \pm 0.07^{\mathrm{a}}$ & $2.59 \pm 0.02^{c}$ & $3.86 \pm 0.07^{\mathrm{a}}$ & $3.48 \pm 0.24^{\mathrm{b}}$ \\
\hline $\mathrm{C} 18: 1$ & $21.14 \pm 0.08^{\mathrm{a}}$ & $19.07 \pm 0.07^{\mathrm{b}}$ & $0.29 \pm 0.02^{\mathrm{c}}$ & $0.27 \pm 0.10^{\mathrm{c}}$ \\
\hline $\mathrm{C} 18: 2$ & $27.53 \pm 0.52^{\mathrm{a}}$ & $25.44 \pm 0.27^{\mathrm{b}}$ & $0.27 \pm 0.05^{\mathrm{c}}$ & $0.15 \pm 0.007^{\mathrm{c}}$ \\
\hline $\mathrm{C} 18: 3$ & $3.48 \pm 0.26^{\mathrm{a}}$ & $2.86 \pm 0.07^{\mathrm{b}}$ & $0.14 \pm 0.007^{\mathrm{c}}$ & $0.17 \pm 0.007^{\mathrm{c}}$ \\
\hline $\mathrm{C} 20: 0$ & $0.47 \pm 0.04^{\mathrm{a}}$ & $0.34 \pm 0.007^{\mathrm{bc}}$ & $0.39 \pm 0.04^{\mathrm{ab}}$ & $0.25 \pm 0.05^{\mathrm{c}}$ \\
\hline $\mathrm{C} 20: 1$ & $0.30 \pm 0.06^{\mathrm{bc}}$ & $0.17 \pm 0.007^{\mathrm{c}}$ & $0.47 \pm 0.09^{\mathrm{a}}$ & $0.36 \pm 0.03^{\mathrm{ab}}$ \\
\hline $\mathrm{C} 20: 2$ & $0.07 \pm 0.007^{\mathrm{c}}$ & $0.08 \pm 0.007^{c}$ & $0.30 \pm 0.01^{b}$ & $0.40 \pm 0.01^{\mathrm{a}}$ \\
\hline $\mathrm{C} 20: 4$ & $2.62 \pm 0.55^{\mathrm{a}}$ & $0.60 \pm 0.11^{\mathrm{b}}$ & $0.31 \pm 0.03^{\mathrm{b}}$ & ND \\
\hline $\mathrm{C} 22: 0$ & $2.03 \pm 0.03^{\mathrm{a}}$ & $1.07 \pm 0.06^{\mathrm{b}}$ & ND & $0.16 \pm 0.02^{\mathrm{c}}$ \\
\hline $\mathrm{C} 22: 1$ & $0.66 \pm 0.06$ & $1.04 \pm 0.02$ & ND & ND \\
\hline $\mathrm{C} 20: 5$ & $0.85 \pm 0.09$ & $0.06 \pm 0.01$ & ND & ND \\
\hline $\mathrm{C} 22: 2$ & $0.14 \pm 0.05$ & $0.03 \pm 0.007$ & ND & ND \\
\hline $\mathrm{C} 24: 0$ & $0.78 \pm 0.07$ & $0.03 \pm 0.007$ & $0.35 \pm 0.07$ & $0.27 \pm 0.03$ \\
\hline $\mathrm{C} 24: 1$ & $0.05 \pm 0.007$ & $0.03 \pm 0.03$ & ND & ND \\
\hline $\mathrm{C} 22: 6$ & $0.48 \pm 0.04$ & $0.36 \pm 0.06$ & ND & ND \\
\hline
\end{tabular}

The different letters are significantly different $(p<0.05)$. $\mathrm{F}_{0}$ : control (sour fruits); $\mathrm{FS}_{2}$ : sour fruits containing $3 \%$ S. ilicifolium; $\mathrm{FG}_{2}$ : sour fruits containing $3 \%$ U. lactuca; $\mathrm{FU}_{2}$ : sour fruits containing $3 \%$ G. cortica. 
TABLe 4: Fatty acid profile of fruit paste samples with 3\% algae powder.

\begin{tabular}{|c|c|c|c|c|}
\hline Fatty acids & $\mathrm{LS}_{4}$ & $\mathrm{LG}_{4}$ & $\mathrm{LU}_{4}$ & $\mathrm{~L}_{0}$ \\
\hline $\mathrm{C} 12: 0$ & $11.56 \pm 0.78^{\mathrm{a}}$ & $2.20 \pm 0.19^{\mathrm{b}}$ & $2.02 \pm 0.02^{\mathrm{b}}$ & $1.29 \pm 0.30^{\mathrm{b}}$ \\
\hline C14:0 & $10.12 \pm 0.007^{\mathrm{a}}$ & $9.48 \pm 0.04^{\mathrm{b}}$ & $1.40 \pm 0.24^{\mathrm{c}}$ & $1.03 \pm 20.02^{\mathrm{C}}$ \\
\hline $\mathrm{C} 16: 0$ & $25.90 \pm 0.62^{\mathrm{a}}$ & $25.28 \pm 0.22^{\mathrm{ab}}$ & $24.04 \pm 0.04^{b c}$ & $23.07 \pm 0.98^{\mathrm{C}}$ \\
\hline $\mathrm{C} 16: 1$ & $1.28 \pm 0.02^{\mathrm{b}}$ & $4.29 \pm 0.37^{\mathrm{a}}$ & $0.35 \pm 0.007^{\mathrm{c}}$ & $0.28 \pm 0.02^{\mathrm{c}}$ \\
\hline $\mathrm{C} 17: 0$ & $1.19 \pm 0.12^{\mathrm{a}}$ & $1.18 \pm 0.22^{\mathrm{a}}$ & $1.13 \pm 10.16^{\mathrm{a}}$ & $0.92 \pm 0.05^{\mathrm{a}}$ \\
\hline $\mathrm{C} 17: 1$ & $1.12 \pm 0.04^{\mathrm{a}}$ & $1.10 \pm 0.09^{\mathrm{a}}$ & $1.07 \pm 0.02^{\mathrm{a}}$ & $0.86 \pm 0.11^{\mathrm{a}}$ \\
\hline $\mathrm{C} 18: 0$ & $22.99 \pm 0.77^{\mathrm{a}}$ & $20.35 \pm 0.30^{b}$ & $16.68 \pm 0.16^{\mathrm{c}}$ & $14.96 \pm 0.06^{\mathrm{c}}$ \\
\hline $\mathrm{C} 18: 1$ & $43.29 \pm 0.29^{\mathrm{c}}$ & $46.31 \pm 0.41^{\mathrm{b}}$ & $52.12 \pm 0.21^{\mathrm{a}}$ & $32.21 \pm 0.04^{\mathrm{d}}$ \\
\hline $\mathrm{C} 18: 2$ & $46.17 \pm 0.79^{b}$ & $40.24 \pm 0.04^{\mathrm{c}}$ & $47.86 \pm 0.84^{\mathrm{a}}$ & $13.20 \pm 0.31^{\mathrm{d}}$ \\
\hline $\mathrm{C} 18: 3$ & $6.31 \pm 0.59^{\mathrm{b}}$ & $7.30 \pm 0.07^{\mathrm{ab}}$ & $8.30 \pm 0.35^{\mathrm{a}}$ & $3.49 \pm 0.39^{c}$ \\
\hline $\mathrm{C} 20: 0$ & $1.23 \pm 0.25^{\mathrm{b}}$ & $1.42 \pm 0.08^{\mathrm{b}}$ & $2.20 \pm 0.20^{\mathrm{a}}$ & $0.21 \pm 0.02^{c}$ \\
\hline $\mathrm{C} 20: 1$ & $0.02 \pm 0.007^{\mathrm{b}}$ & $0.05 \pm 0^{\mathrm{ab}}$ & $0.14 \pm 0.06^{\mathrm{a}}$ & ND \\
\hline $\mathrm{C} 20: 2$ & $0.11 \pm 0.01^{\mathrm{b}}$ & $0.21 \pm 0.007^{\mathrm{a}}$ & $0.03 \pm 0^{c}$ & ND \\
\hline $\mathrm{C} 20: 4$ & $0.16 \pm 0.07$ & $0.71 \pm 0.14$ & ND & ND \\
\hline $\mathrm{C} 22: 0$ & $0.43 \pm 0.07^{\mathrm{c}}$ & $1.19 \pm 0.01^{\mathrm{a}}$ & $0.94 \pm 0.007^{\mathrm{b}}$ & $0.21 \pm 0.01^{\mathrm{d}}$ \\
\hline $\mathrm{C} 22: 1$ & ND & $1.27 \pm 0.02$ & ND & ND \\
\hline $\mathrm{C} 20: 5$ & $0.60 \pm 0.02$ & $0.08 \pm 0.01$ & ND & ND \\
\hline $\mathrm{C} 22: 2$ & $0.10 \pm 0.02$ & $0.08 \pm 0.01$ & ND & $2.20 \pm 0.19$ \\
\hline $\mathrm{C} 24: 0$ & $0.16 \pm 0.04$ & $0.75 \pm 0.10$ & $0.44 \pm 0.07$ & $0.35 \pm 0.06$ \\
\hline $\mathrm{C} 24: 1$ & ND & $0.65 \pm 0.007$ & ND & ND \\
\hline $\mathrm{C} 22: 6$ & $0.51 \pm 0.19$ & $1.66 \pm 0.09$ & ND & ND \\
\hline
\end{tabular}

The different letters are significantly different $(p<0.05)$. $\mathrm{L}_{0}$ : control (fruit paste); $\mathrm{LS}_{4}$ : fruit paste containing $3 \%$ S. ilicifolium; $\mathrm{LG}_{4}$ : fruit paste containing $3 \%$ U. lactuca; $\mathrm{LU}_{4}$ : fruit paste containing $3 \%$ G. cortica.

TABle 5: Fatty acid profile of sour fruit samples with $1.5 \%$ algae powder.

\begin{tabular}{|c|c|c|c|c|}
\hline Fatty acids & $\mathrm{FS}_{1}$ & $\mathrm{FG}_{1}$ & $\mathrm{FU}_{1}$ & $\mathrm{~F}_{0}$ \\
\hline $\mathrm{C} 12: 0$ & $0.7 \pm 0.01^{\mathrm{a}}$ & $0.34 \pm 0.01^{\mathrm{b}}$ & $0.77 \pm 0.02^{\mathrm{a}}$ & $0.68 \pm 0.04^{\mathrm{a}}$ \\
\hline $\mathrm{C} 14: 0$ & $0.82 \pm 0.01^{\mathrm{b}}$ & $0.73 \pm 0.08^{\mathrm{b}}$ & $1.40 \pm 0.02^{\mathrm{a}}$ & $1.29 \pm 0.29^{\mathrm{a}}$ \\
\hline $\mathrm{C} 16: 0$ & $14.46 \pm 0.18^{c}$ & $17.16 \pm 0.06^{\mathrm{b}}$ & $26.17 \pm 0.22^{\mathrm{a}}$ & $25.61 \pm 0.72^{\mathrm{a}}$ \\
\hline $\mathrm{C} 16: 1$ & $2.59 \pm 0.02^{\mathrm{b}}$ & $3.17 \pm 0.09^{\mathrm{a}}$ & $1.20 \pm 0.01^{\mathrm{c}}$ & $1.15 \pm 0.007^{\mathrm{c}}$ \\
\hline $\mathrm{C} 17: 0$ & $0.53 \pm 0.07^{\mathrm{b}}$ & $0.12 \pm 0^{c}$ & $1.23 \pm 0.02^{\mathrm{a}}$ & $1.13 \pm 0.02^{\mathrm{a}}$ \\
\hline $\mathrm{C} 17: 1$ & $0.13 \pm 0.02^{\mathrm{a}}$ & $0.06 \pm 0.02^{\mathrm{b}}$ & $0.15 \pm 0.02^{\mathrm{a}}$ & $0.11 \pm 0.007^{\mathrm{ab}}$ \\
\hline $\mathrm{C} 18: 0$ & $2.29 \pm 0.02^{\mathrm{b}}$ & $1.23 \pm 0.08^{\mathrm{c}}$ & $3.38 \pm 0.01^{\mathrm{a}}$ & $3.48 \pm 0.24^{\mathrm{a}}$ \\
\hline $\mathrm{C} 18: 1$ & $18.05 \pm 0.04^{\mathrm{a}}$ & $15.49 \pm 0.04^{\mathrm{b}}$ & $0.29 \pm 0.02^{\mathrm{c}}$ & $0.27 \pm 0.10^{c}$ \\
\hline $\mathrm{C} 18: 2$ & $17.13 \pm 0.02 / 0^{\mathrm{a}}$ & $17.08 \pm 0.07^{\mathrm{a}}$ & $0.16 \pm 0.01^{b}$ & $0.15 \pm 0.007^{\mathrm{b}}$ \\
\hline $\mathrm{C} 18: 3$ & $1.43 \pm 0.13^{\mathrm{a}}$ & $1.07 \pm 0.07^{\mathrm{b}}$ & $0.18 \pm 0.01^{\mathrm{c}}$ & $0.17 \pm 0^{\mathcal{C}}$ \\
\hline $\mathrm{C} 20: 0$ & $0.30 \pm 0.02^{\mathrm{a}}$ & $0.17 \pm 0.02^{\mathrm{b}}$ & $0.34 \pm 0.02^{\mathrm{a}}$ & $0.25 \pm 0.05^{\mathrm{ab}}$ \\
\hline $\mathrm{C} 20: 1$ & $0.13 \pm 0.02^{\mathrm{b}}$ & $0.08 \pm 0.01^{\mathrm{b}}$ & $0.40 \pm 0.007^{\mathrm{a}}$ & $0.36 \pm 0.03^{\mathrm{a}}$ \\
\hline $\mathrm{C} 20: 2$ & $0.02 \pm 0.01^{\mathrm{b}}$ & $0.03 \pm 0.02^{\mathrm{b}}$ & $0.15 \pm 0.05^{\mathrm{a}}$ & $0.40 \pm 0.01^{\mathrm{a}}$ \\
\hline $\mathrm{C} 20: 4$ & $1.20 \pm 0.07$ & $0.36 \pm 0.06$ & ND & ND \\
\hline $\mathrm{C} 22: 0$ & $1.06 \pm 0.04^{\mathrm{a}}$ & $0.63 \pm 0.13^{\mathrm{b}}$ & ND & $0.16 \pm 0.02^{c}$ \\
\hline $\mathrm{C} 22: 1$ & $0.50 \pm 0.05$ & $0.76 \pm 0.15$ & ND & ND \\
\hline $\mathrm{C} 20: 5$ & $0.22 \pm 0.02$ & $0.04 \pm 0.01$ & ND & ND \\
\hline $\mathrm{C} 22: 2$ & $0.06 \pm 0.03$ & $0.03 \pm 0.002$ & ND & ND \\
\hline $\mathrm{C} 24: 0$ & $0.12 \pm 0.01^{c}$ & $0.42 \pm 0.01^{\mathrm{a}}$ & $0.38 \pm 0.02^{\mathrm{a}}$ & $0.27 \pm 0.03^{\mathrm{b}}$ \\
\hline $\mathrm{C} 24: 1$ & $0.06 \pm 0.01$ & $0.04 \pm 0.01$ & ND & ND \\
\hline $\mathrm{C} 22: 6$ & $0.29 \pm 0.02$ & $0.17 \pm 0.07$ & ND & ND \\
\hline
\end{tabular}

Different letters indicate significant differences $(p<0.05) . \mathrm{F}_{0}$ : control (sour fruits); $\mathrm{FS}_{1}$ : sour fruits containing $1.5 \%$ S. ilicifolium; $\mathrm{FG}_{1}$ : sour fruits containing $1.5 \%$ U. lactuca; $\mathrm{FU}_{1}$ : sour fruits containing $1.5 \%$ G. cortica.

were palmitic acid (C16:0), stearic acid (C18:0), oleic acid $(\mathrm{C} 18: 1)$, and linoleic acid $(\mathrm{C} 18: 2)$. Also, minor quantities of other fatty acids including linolenic acid (C18:3), behenic acids (C22:0), and arachidonic acid (C20:4) were found in these products. The fatty acids including $\mathrm{C} 20: 4, \mathrm{C} 20: 5$, C22:1, C22:2, C22:6, C24:1 and C20:1, C20:2, C20:4, $\mathrm{C} 20: 5, \mathrm{C} 22: 1, \mathrm{C} 22: 6$, and $\mathrm{C} 24: 1$ were not observed in control sour fruits and control fruit paste, respectively. In the case of functional processed fruits containing U. lactuca algae, some fatty acids such as C22:0, C22:1, C22:2, C22:6, C20:5, and C24:1 were not observed. Besides, fatty acid C20: 4 was not reported in sour fruits with $1.5 \%$ U. lactuca algae.

All processed samples showed a high concentration of PUFAs (C20:4, C20:5, C22:6). $\omega-3$ fatty acids, eicosapentaenoic (EPA, C20:5) and docosahexaenoic (DHA, C22: 
TABLE 6: Fatty acid profile of fruit paste samples with $1.5 \%$ algae powder.

\begin{tabular}{|c|c|c|c|c|}
\hline Fatty acids & $\mathrm{LS}_{3}$ & $\mathrm{LG}_{3}$ & $\mathrm{LU}_{3}$ & $\mathrm{~L}_{0}$ \\
\hline $\mathrm{C} 12: 0$ & $7.17 \pm 00.56^{\mathrm{a}}$ & $6.17 \pm 0.11^{\mathrm{a}}$ & $2.70 \pm 0.080^{\mathrm{b}}$ & $1.29 \pm 0.30^{\mathrm{b}}$ \\
\hline C14:0 & $6.36 \pm 0.21^{\mathrm{a}}$ & $5.50 \pm 0.54^{\mathrm{b}}$ & $1.99 \pm 0.12^{\mathrm{c}}$ & $1.03 \pm 0.02^{\mathrm{d}}$ \\
\hline $\mathrm{C} 16: 0$ & $14.32 \pm 0.15^{\mathrm{c}}$ & $15.14 \pm 0.22^{\mathrm{b}}$ & $24.04 \pm 0.18^{\mathrm{d}}$ & $10.72 \pm 0.27^{\mathrm{a}}$ \\
\hline $\mathrm{C} 16: 1$ & $0.61 \pm 0.10^{\mathrm{a}}$ & $0.75 \pm 0.08^{\mathrm{a}}$ & $0.02 \pm 0.01^{\mathrm{c}}$ & $0.28 \pm 0.02^{\mathrm{b}}$ \\
\hline $\mathrm{C} 17: 0$ & $0.84 \pm 0.42^{\mathrm{b}}$ & $0.64 \pm 0.01^{\mathrm{b}}$ & $0.05 \pm 0.007^{\mathrm{c}}$ & $0.92 \pm 0.05^{\mathrm{a}}$ \\
\hline $\mathrm{C} 17: 1$ & $0.89 \pm 0.03^{\mathrm{b}}$ & $0.68 \pm 0.07^{c}$ & $0.28 \pm 0.07^{\mathrm{d}}$ & $0.86 \pm 0.11^{\mathrm{a}}$ \\
\hline $\mathrm{C} 18: 0$ & $14.41 \pm 0.25^{\mathrm{c}}$ & $15.53 \pm 0.24^{\mathrm{b}}$ & $9.19 \pm 0.98^{\mathrm{d}}$ & $14.96 \pm 0.06^{\mathrm{a}}$ \\
\hline $\mathrm{C} 18: 1$ & $21.20 \pm 0.24^{\mathrm{b}}$ & $17.27 \pm 0.34^{\mathrm{c}}$ & $8.44 \pm 0.26^{\mathrm{d}}$ & $32.21 \pm 0.04^{\mathrm{a}}$ \\
\hline $\mathrm{C} 18: 2$ & $25.24 \pm 0.30^{b}$ & $23.10 \pm 0.12^{c}$ & $6.07 \pm 0.06^{\mathrm{d}}$ & $13.20 \pm 0.31^{\mathrm{a}}$ \\
\hline $\mathrm{C} 18: 3$ & $1.29 \pm 0.09^{\mathrm{b}}$ & $1.07 \pm 0.06$ & $0.07 \pm 0.01^{c}$ & $3.49 \pm 0.39^{\mathrm{a}}$ \\
\hline $\mathrm{C} 20: 0$ & $0.42 \pm 0.09^{\mathrm{b}}$ & $0.31 \pm 0.01^{\mathrm{c}}$ & $0.01 \pm 0.007^{\mathrm{bc}}$ & $0.21 \pm 0.02^{\mathrm{a}}$ \\
\hline $\mathrm{C} 20: 1$ & $0.02 \pm 0.01^{\mathrm{b}}$ & $0.02 \pm 0.007^{\mathrm{ab}}$ & $0.14 \pm 0.06^{\mathrm{a}}$ & ND \\
\hline $\mathrm{C} 20: 2$ & $0.07 \pm 0.007^{\mathrm{a}}$ & $0.04 \pm 0.01^{\mathrm{b}}$ & $0.03 \pm 0$ & ND \\
\hline $\mathrm{C} 20: 4$ & $0.07 \pm 0.007$ & $0.02 \pm 0$ & ND & ND \\
\hline $\mathrm{C} 22: 0$ & $0.14 \pm 0.007^{\mathrm{c}}$ & $0.15 \pm 0.02^{\mathrm{c}}$ & $0.22 \pm 0.02^{\mathrm{b}}$ & $0.21 \pm 0.01^{\mathrm{a}}$ \\
\hline $\mathrm{C} 22: 1$ & ND & $0.13 \pm 0.01$ & ND & ND \\
\hline $\mathrm{C} 20: 5$ & $0.11 \pm 0.01$ & $0.09 \pm 0.07$ & ND & $\mathrm{ND}$ \\
\hline $\mathrm{C} 22: 2$ & $0.14 \pm 0.02$ & $0.13 \pm 0.02$ & ND & ND \\
\hline $\mathrm{C} 24: 0$ & $0.53 \pm 0.007^{\mathrm{a}}$ & $0.57 \pm 0.06^{\mathrm{a}}$ & $0.27 \pm 0.31^{\mathrm{a}}$ & $0.35 \pm 0.06^{\mathrm{a}}$ \\
\hline $\mathrm{C} 24: 1$ & ND & ND & ND & ND \\
\hline $\mathrm{C} 22: 6$ & ND & ND & ND & ND \\
\hline
\end{tabular}

The different letters are significantly different $(p<0.05)$. $\mathrm{L}_{0}$ : control (fruit paste); $\mathrm{LS}_{3}$ : fruit paste containing $1.5 \%$ S. ilicifolium; $\mathrm{LG}_{3}$ : fruit paste containing $1.5 \%$ U. lactuca; $\mathrm{LU}_{3}$ : fruit paste containing $1.5 \%$ G. cortica.

6), were mainly found in processed fruit and fruit paste containing $3 \%$ S. ilicifolium and G. cortica algae, but in this respect, $U$. lactuca and control samples were not reported. $\omega-6$ fatty acids (C18:2) were reported in all samples, but $\omega-6(\mathrm{C} 20$ : 4) fatty acids were not found in control processed fruits, control fruit paste, fruit paste containing U. lactuca algae, and processed fruits containing $1.5 \% \mathrm{U}$. lactuca algae. Linolenic acid was reported in all samples.

Generally, seaweeds are not a good source of fat because they have low total fat and cannot be a good source of energy. However, some of them have been introduced as rich sources of unsaturated fatty acids [27]. Fluctuations in fatty acid content are due to both environmental and genetic differences [28]. Common sources of PUFAs include fish oil, shark liver, salmon, tuna, and sardines [29]. Potential alternatives to these sources include fungi and microalgae [30]. Alternative sources of DHA have gained recent attention because of the concerns about methylmercury contamination in fish and shellfishes [31].

Gouveia et al. [32] reported that S. maxima algae in the herbal jelly desserts improve the level of linolenic acid. $\omega_{3}$ and $\omega_{6}$ fatty acids are present in significant amounts in algae. They are essential fatty acids (EFAs) for the body, meaning that the body is unable to produce them and must be supplied through food. Deficiency of essential fatty acids, especially $\omega-3$, is very common and causes serious diseases such as heart attack, cancer, insulin resistance, asthma, lupus, schizophrenia, depression, postpartum depression, premature aging, clogged arteries, obesity, diabetes, osteoarthritis, and Alzheimer's disease. Thus, introducing new and available sources of $\omega_{3}$ and $\omega_{6}$ fatty acids can be an effective step in improving community health [33].
Gosch et al. [34] reported that docosahexaenoic acid (DHA, C22:6) is the most common polyunsaturated fatty acid in the green seaweeds compared to the brown and red seaweeds. By contrast, Khairy and El-Shafay [35] found that it was a primary component in several macroalgae. Belarbi et al. [36] and Chisti [37] reported that algal oils are relatively rich in polyunsaturated fatty acids with four or more double bonds, such as docosahexaenoic acid, which commonly occurs in algal oils.

Similar results were reported by Rohani-Ghadikolaei et al. [38], Banamoon [39], Tabarsa et al. [40], Pereira et al. [41], and Muralidhar et al. [42], on sea lettuce (U. lactuca), showing that saturated fatty acids are higher than unsaturated fatty acids and palmitic acid is the most abundant fatty acid. Khairy and El-Shafay [35] showed that the total fat content of sea lettuce collected from the coast of Alexandria in Egypt was equivalent to 4\%. The amount of saturated fatty acid was higher than that of unsaturated fatty acid, and the highest amount of saturated fatty acid was of palmitic acid but with an average of about 70\%. Pereira et al. [41], in a study on sea lettuce (U. lactuca) fatty acids, found that the predominant fatty acid in sea lettuce of the coast of Portugal oil is palmitic acid with $59 \%$.

Changes in fatty acid profiles can be attributed to seasonal changes and environmental factors. Banamoon [39] investigated the fat content and fatty acid composition of 20 species of algae on the coast of Yemen, including several species of green, red, and brown algae. Their results showed that the oil content was about $4 \%$ in U. lactuca algae and the predominant fatty acids in this species of algae were $\mathrm{C} 16: 0$, $\mathrm{C} 18: 3, \mathrm{C} 18: 2$, and C18:1. Tabarsa et al. [40] showed that the main fatty acids of $U$. lactuca algae oil were $\mathrm{C} 18: 3, \mathrm{C} 18$ : 2, C18:0, C16:0, C14:0, and C12:0. Muralidhar et al. [42] 
studied the fat content and fatty acid composition of three species of U. lactuca, Sargassum wightii, and Kappaphycus alvarezii algae on the east coast of India and reported 5\% $\omega-6$ fatty acids and $3-4 \% \omega-3$ in the tested species.

It is notable that, in none of the studies, caproic acid was found. Tebarsa et al. [40] compared the amount of fatty acid between two red Gracilaria salicornia algae and the green $U$. lactuca alga and reported the amount of saturated and unsaturated fatty acids in these algae is 48.95-38.66 and 48.34-29.95, respectively. Pereira et al. [41] reported the sea lettuce (U. lactuca) contains $59.04 \%$ and $40.96 \%$ of saturated and unsaturated fatty acids, respectively. The highest amount of linoleic acid was reported by Banamoon [39] in Yemen with a rate of $6.5 \%$. Linolenic acid was reported by Muralidhar et al. [42] and Pereira et al. [41] to be about 3\% and $16.5 \%$, respectively.

Our results showed that the S. ilicifolium, G. cortica, and $U$. lactuca algae can be suggested as a rich source of $\omega_{3}$ and $\omega_{6}$ fatty acids. Generally, PUFAs have an essential role in human nutrition and health maintenance. But, the potential negative effects of seaweeds on human health and corresponding samples containing high levels of palmitic acid must be considered [7].

3.2. Vitamin Contents. The level of vitamins in sour fruits and fruit pastes containing $3 \%$ and $1.5 \%$ S. ilicifolium, U. lactuca, and G. cortica algae is summarized in Figures 1-4. As it can be seen from figures, vitamins $\mathrm{E}(7.20-20.30 \mathrm{mg} / \mathrm{g})$ and $\mathrm{B}_{1}(7.31-18.48 \mathrm{mg} / \mathrm{g})$ in sour fruits and vitamins $\mathrm{E}$ $(6.19-22.63 \mathrm{mg} / \mathrm{g}), \quad \mathrm{C} \quad(5.08-16.34 \mathrm{mg} / \mathrm{g})$, and $B_{1}$ $(5.38-19.10 \mathrm{mg} / \mathrm{g})$ in fruit paste were observed significantly more than other vitamins $(p<0.05)$. Also, small amounts of vitamins $A, B_{2}$, and $B_{3}$ were reported in these products. There were no significant differences in the content of vitamin $B_{3}$ in all samples of fruit pastes containing $3 \%$ of all three algae $(p<0.05)$. Overall, theses algae were not shown to be good sources of riboflavin.

The recommended daily allowances (RDAs) of riboflavin for adults are 1.3. A realistic daily portion of $S$. ilicifolium, U. lactuca, and G. cortica algae contribute $5-14 \%$ to the daily requirements of riboflavin. U. lactuca had the highest vitamin E, followed by S. ilicifolium and G. cortica in sour fruits. Vitamin E content of sour fruits and fruit pastes containing $1.5 \%$ algae was lower than in the control sample $(p<0.05)$.

The results also showed that the vitamin contents in the samples increased with algae concentration, so the highest amount was observed in treatments containing 3\% algae.

Orders et al. [43] enriched mozzarella cheese using Porphyridium cruentum alga to increase tocopherol content in the cheese and inhibition of DHA reduction for 4 weeks.

Vitamins are organic macronutrients with catalytic effects on metabolic reactions in humans. However, autotrophic organisms can synthesize vitamins, but heterotrophic organisms, including humans, are only able to synthesize vitamins to a restricted extent. Thus, vitamins must be obtained from the diet, and they are called endogenous essential catalysts. Seaweed is a significant source of some water-soluble and lipid-soluble vitamins. Seaweeds have been reported to have a higher content of vitamin $\mathrm{E}$, and green and red seaweed are poor in vitamin E [44]. Brown algae usually have higher vitamin $\mathrm{C}$ content than red and green algae. Nutritional compositions of brown algae and its application in aquaculture have been previously reported $[45,46]$. The chemical composition of seaweed varies depending on the type of species and the different physiological and environmental conditions. However, macroalgae are rich in nonstarch polysaccharides, vitamins, and minerals [47].

Zhao and Zhao [8] were able to produce a rich yogurt in a variety of vitamins, micronutrients, and proteins by adding 3\% Spirulina Platensis powder. They improved the nutritional value and taste of the final product. In another study by Mamatha et al. [9], the nutritional properties of snack called Pacado have been improved by using the Entromorpha comprsa. The results showed an increase in dietary fiber, protein, ash, phenol content, and free-radical scavenging activity [9].

De-Marco et al. [10] investigated the effect of mixing spirulina biomass with wheat flour to produce dry paste in three concentrations of 5, 10, and $20 \%$. Their results showed that the content of phenolic compounds and antioxidant activity was evaluated in vitro. The results showed an increase in antioxidant activity and the amount of these substances compared to the control sample. This evidence suggested the improvement of functional, biological, and nutritional properties of pasta containing Spirulina microalgae [10].

3.3. Mineral Contents. The mineral content of sour fruits and fruit pastes containing $3 \%$ and $1.5 \%$ S. ilicifolium, U. lactuca, and G. cortica algae is shown in Figures 5-8. The results showed that all three species of the studied algae are very rich in iodine, which can play a role in the transfer of this mineral to the secondary consumer, i.e., humans. However, more studies are needed in this regard. The content of iodine in the samples ranged from 5.06 to $607.46 \mathrm{mg} / \mathrm{g}$, and the content increased significantly with the algae concentration $(p<0.05)$. Other minerals such as iron, calcium, magnesium, and zinc were also reported in our study. The highest concentration of zinc was observed in sour fruits and fruit paste with $3 \% U$. lactuca and S. ilicifolium, respectively. Also, the zinc level of sour fruits containing $3 \%$ algae is not significantly different $(p>0.05)$.

Geographical variations affect the composition of seaweed for various reasons, including the availability of sunlight, the uptake of minerals, and tidal flows. The results of the present study were in agreement with the findings of Golmakani et al. [11]. An enriched Yazdi cake using Spirulina platensis microalgae was produced to increase the levels of iron, selenium, phosphorus, magnesium, magnesium, and calcium. Branger et al. [48] found that the formulation of spirulina-enriched cakes had a higher ash content due to the presence of iron, calcium, potassium, manganese, copper, zinc, magnesium, and selenium in the microalgae. 


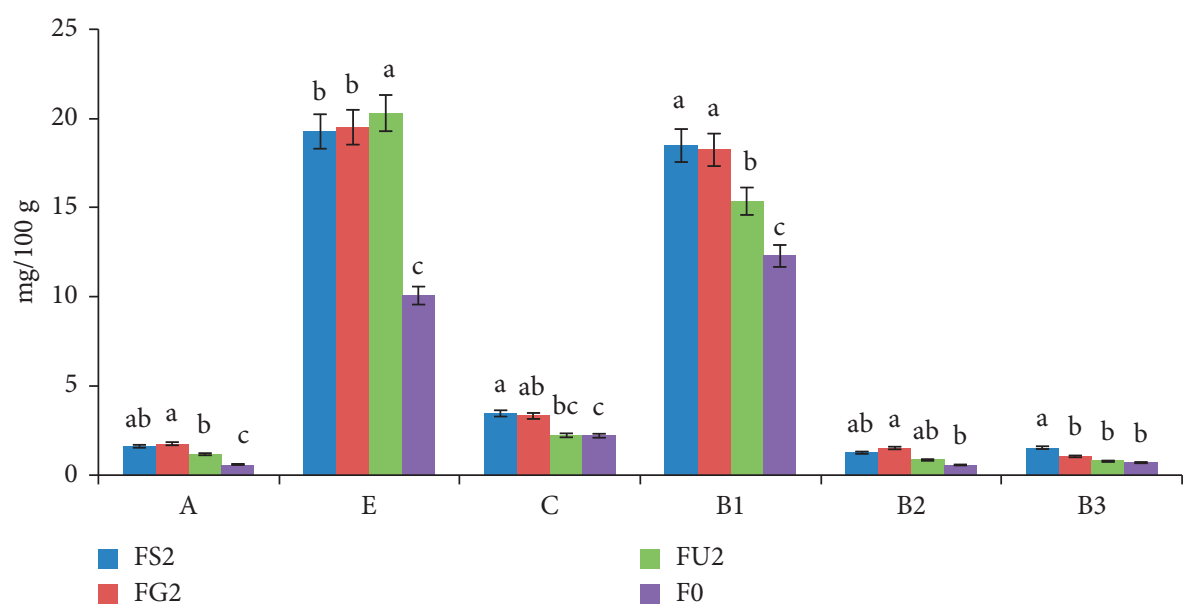

FIGURE 1: Vitamin content of sour fruits with $3 \%$ algae powder. Different letters indicate significant differences $(p<0.05)$.

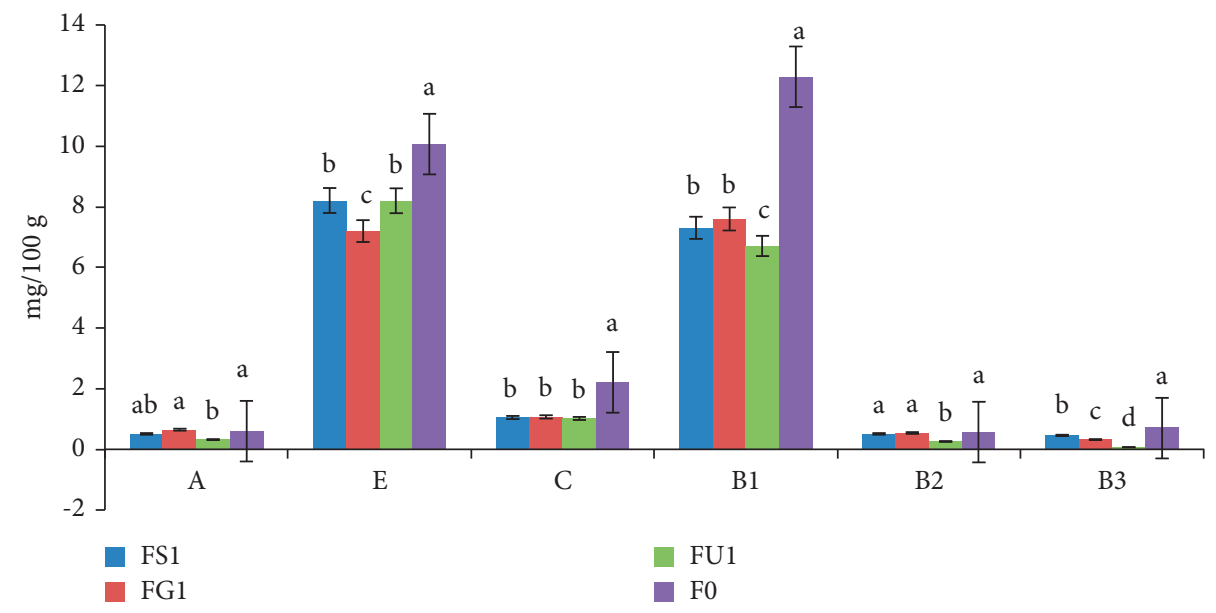

Figure 2: Vitamin content of sour fruits with $1.5 \%$ algae powder. Different letters indicate significant differences $(p<0.05)$.

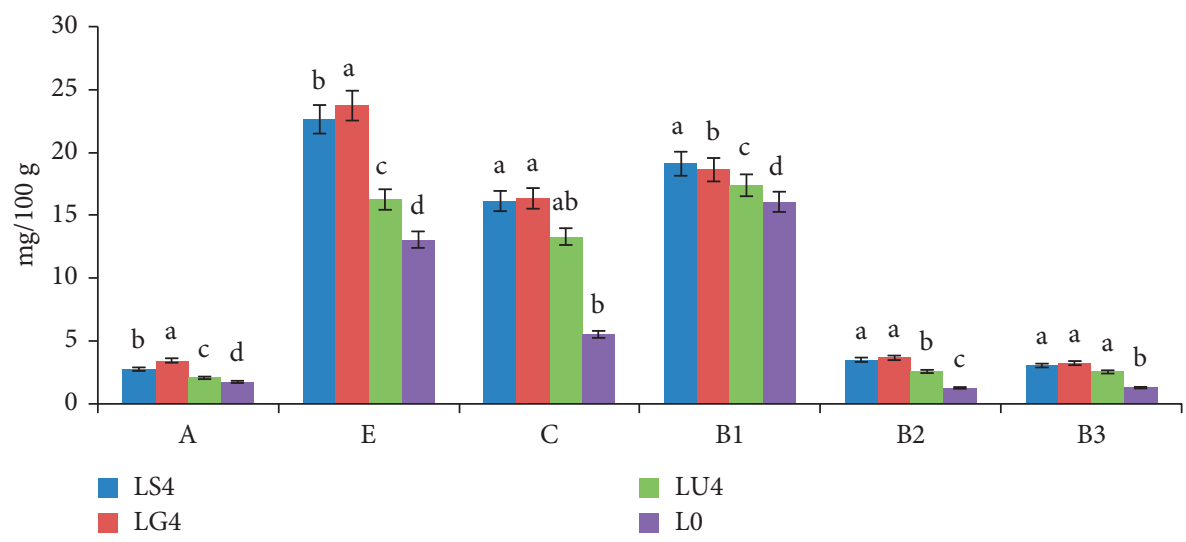

Figure 3: Vitamin content of fruit paste with $3 \%$ algae powder. Different letters indicate significant differences $(p<0.05)$. 


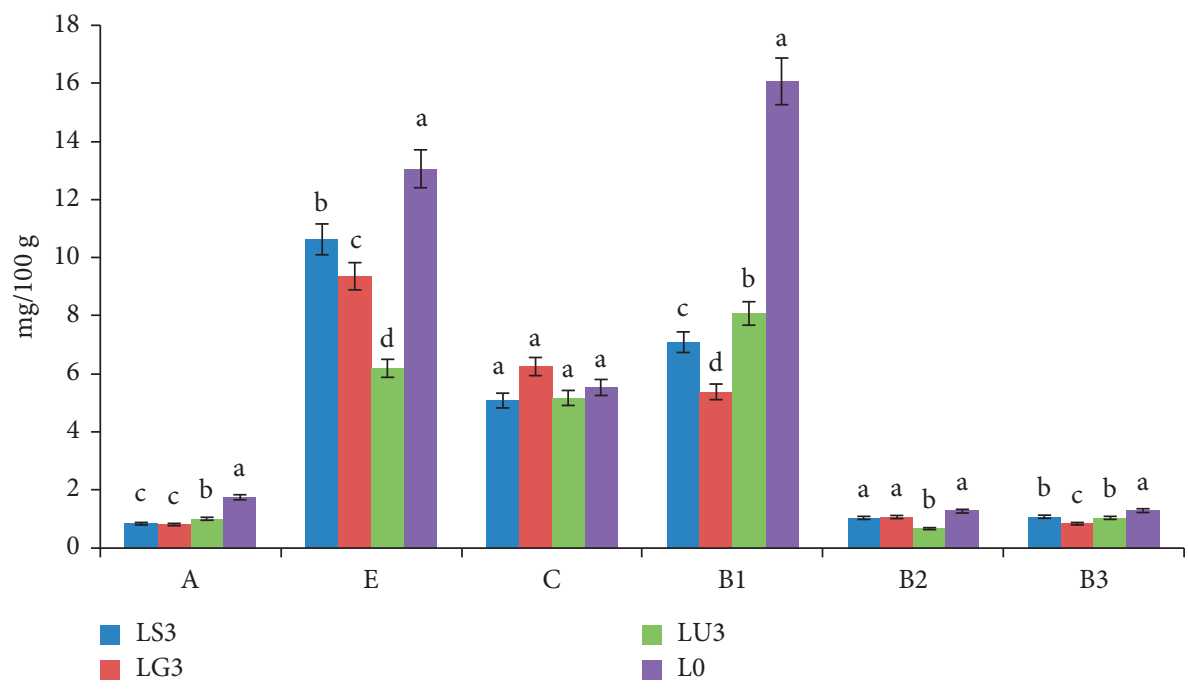

Figure 4: Vitamin content of fruit paste with $1.5 \%$ algae powder. Different letters indicate significant differences $(p<0.05)$.

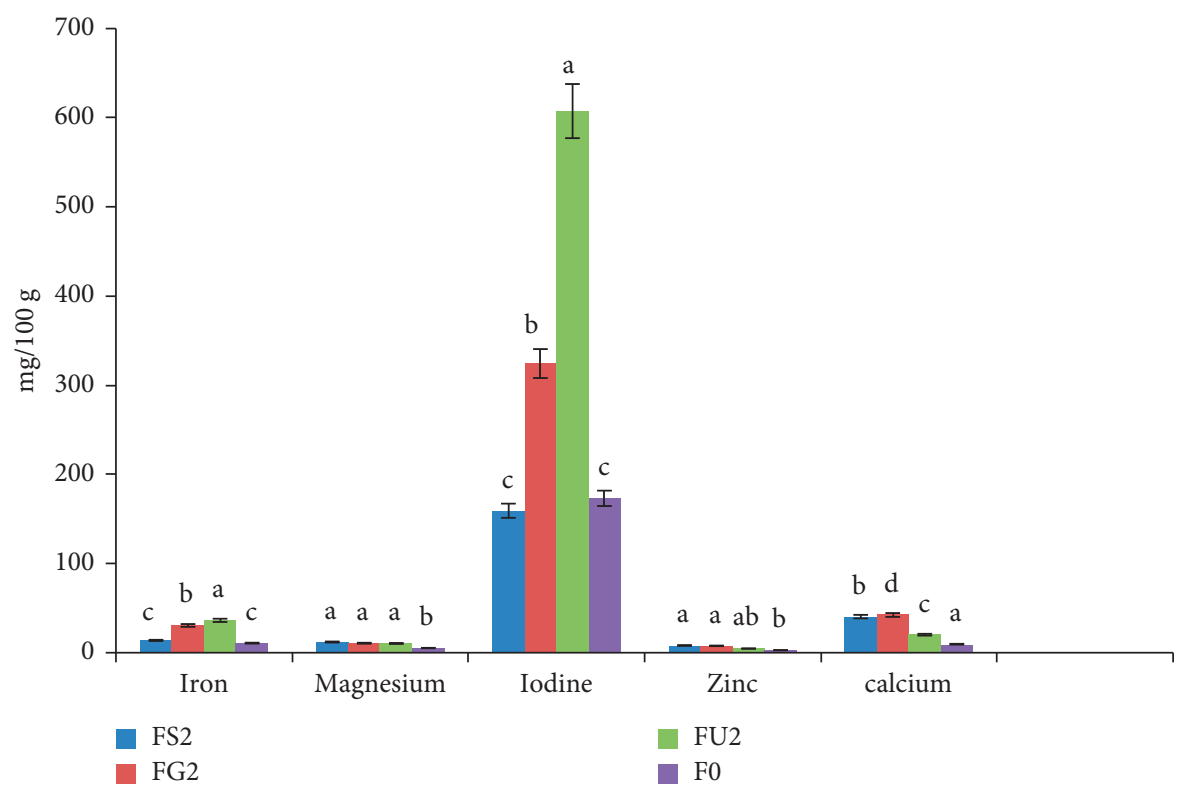

Figure 5: Mineral content of sour fruits with 3\% algae powder. Different letters indicate significant differences $(p<0.05)$.

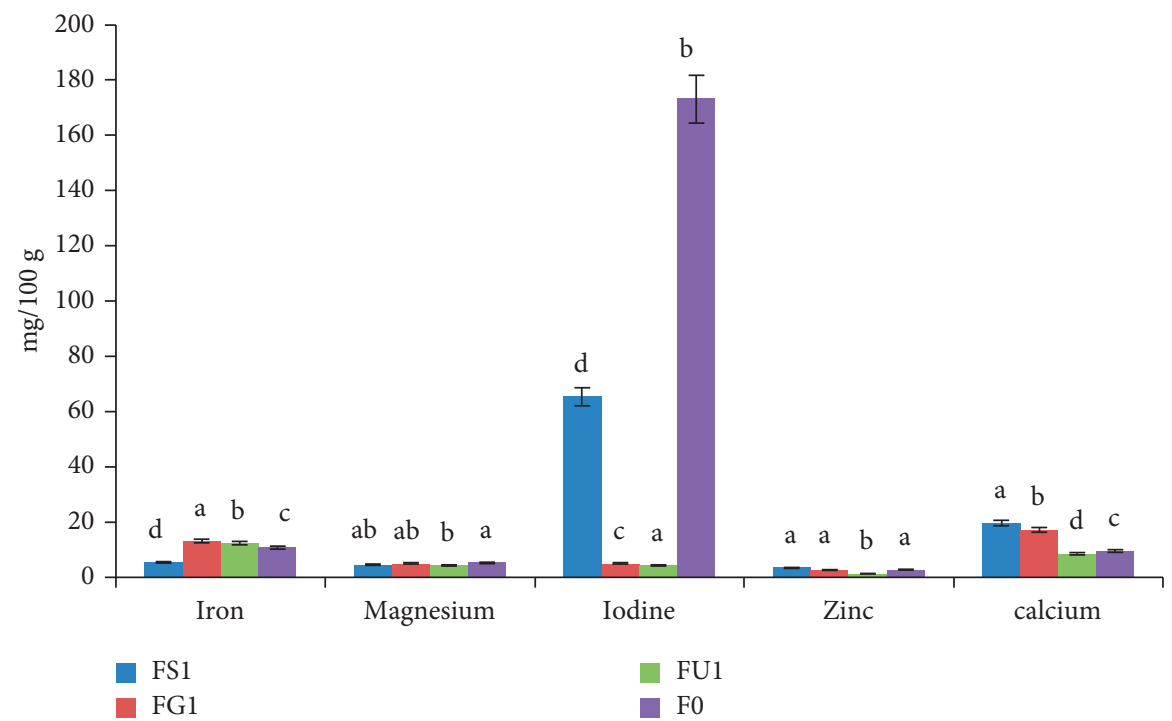

Figure 6: Mineral content of sour fruits with $1.5 \%$ algae powder. Different letters indicate significant differences $(p<0.05)$. 


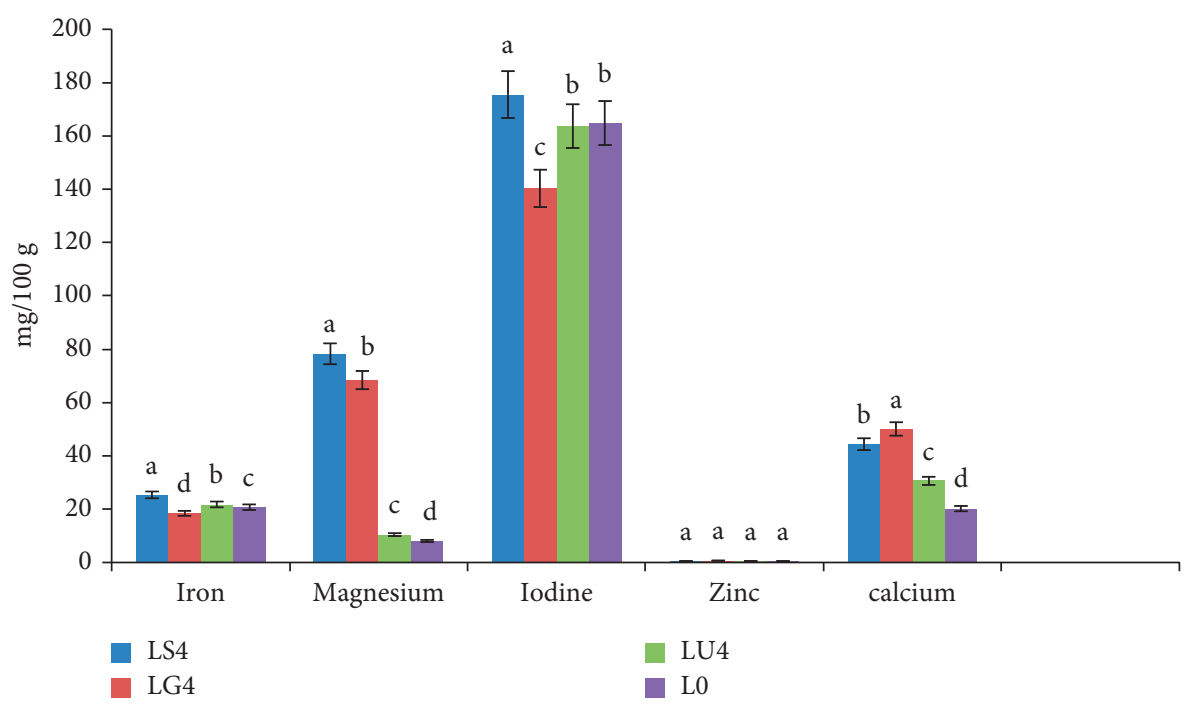

Figure 7: Mineral content of fruit paste with 3\% algae powder. Different letters indicate significant differences $(p<0.05)$.

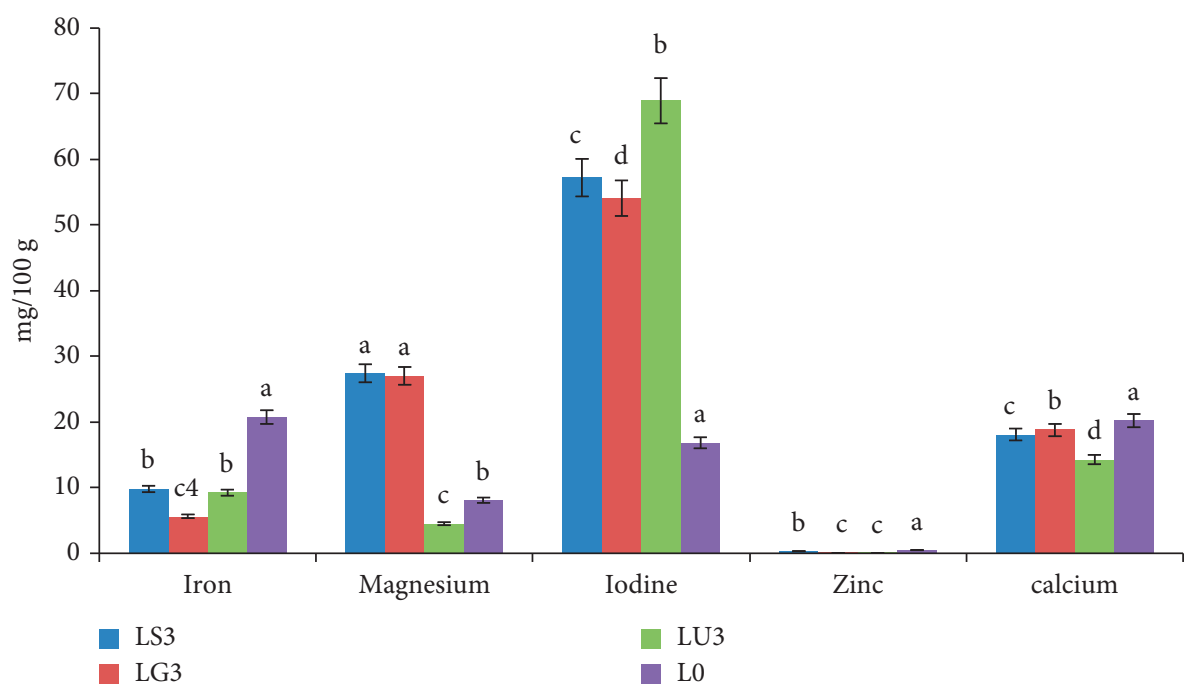

Figure 8: Mineral content of fruit paste with $1.5 \%$ algae powder. Different letters indicate significant differences $(p<0.05)$.

Iron is not properly absorbed in some supplements. Iron has been reported to be better absorbed in algae than iron sulfate and other components. As a result, seaweed can be a sufficient source of iron for anemic pregnant women [49]. Mazinani et al. [50] reported a significant increase in the amount of iron in cheeses fortified with the Spirulina Platensis alga. Differences in the biosorption of minerals by algae may be affected by the composition of polysaccharides in their cell walls [51].

\section{Conclusions}

S. ilicifolium, U. lactuca, and G. cortica algae in the concentration of $3 \%$ and $1.5 \%$ are relatively good sources of essential fatty acids (high levels of omega-3), vitamins, and minerals. All samples contained saturated and unsaturated fatty acids such as palmitic acid, stearic acid, oleic acid, and linoleic acid. Vitamins $E, B_{1}, C, B_{2}$, and $B_{3}$ were observed in all functional products. All samples were rich in iodine, iron, calcium, magnesium, and zinc content. Therefore, due to the presence of vitamins, essential fatty acids, and trace elements of natural origin, these algae provide new opportunities in the production of functional products. Also, according to the studies on iron and iodine deficiency in the country and the popularity of processed fruits, especially among children in Iran, adding algae to these products can improve human health. However, the presence of saturated fatty acids such as palmitic acid in these products should be given more attention.

\section{Data Availability}

The data used to support the findings of this study are available from the corresponding author upon request. 


\section{Conflicts of Interest}

The authors have no conflicts of interest to report.

\section{Acknowledgments}

The authors are grateful to the respected authorities of the research lab at the Science and Research Branch, Islamic Azad University, Tehran, Iran.

\section{References}

[1] WHO/FAO, Diet, Nutrition and the Presentation of Chronic Diseases, Report of the Joint WHO/FAO Expert Consultation on Diet, Nutrition and the Prevention of Chronic Diseases, WHO/FAO, Geneva, Switzerland, 2002.

[2] E. Betoret, N. Betoret, D. Vidal, and P. Fito, "Functional foods development: trends and technologies," Trends in Food Science \& Technology, vol. 22, no. 9, pp. 498-508, 2011.

[3] R. G. Abirami and S. Kowsalya, "Nutrient and nutraceutical potentials of seaweed biomass Ulva lactuca and Kappaphycus alvarezii," Nong Ye Ke Xue Yu Ji Shu, vol. 5, no. 1, 2011.

[4] T. Yu-Qing, K. Mahmood, R. Shehzadi, and M. F. Ashraf, "Ulva lactuca and its polysaccharides: food and biomedical aspects," Journal of Biology, Agriculture and Healthcare, vol. 6, no. 1, pp. 140-151, 2016.

[5] D. J. McHugh, "A guide to seaweed industry," in FAO Fisheries Technical Paper, FAO, Ed., pp. 1-118, FAO, Rome, Italy, 2003.

[6] M. Hafezieh, Y. Moradi, M. Pourkazemi, S. Dadgar, and M. Sharifian, "Determination of proximal and chemical composition of Sistan and Baluchistan Province geographical beaches strain of Sargassum ilicifolium," Iranian Scientific Fisheries Journal, vol. 25, no. 4, pp. 133-144, 2017.

[7] C. Soares, S. Sousa, S. Machado et al., "Bioactive lipids of seaweeds from the Portuguese north coast: health benefits versus potential contamination," Foods, vol. 10, no. 6, Article ID 1366, 2021.

[8] X. Zhao and X. Zhao, Study on Spirulina Platensis Nutritious Yogurt, China Dairy Industry (Shandong Medical University) (Shandong Institute of Light Industry), Jinan, China, 1999.

[9] B. Mamatha, K. Namitha, A. Senthil, J. Smitha, and G. Ravishankar, "Studies on use of Enteromorpha in snack food," Food Chemistry, vol. 101, no. 4, pp. 1707-1713, 2007.

[10] E. Rodríguez De Marco, M. E. Steffolani, C. S. Martínez, and A. E. León, "Effects of Spirulina biomass on the technological and nutritional quality of bread wheat pasta," LebensmittelWissenschaft und -Technologie- Food Science and Technology, vol. 58, no. 1, pp. 102-108, 2014.

[11] M. T. Golmakani, M. Moayyedi, A. Raissjalali, Y. Pesaran, and A. Aghajani, "Investigation of physicochemical, nutritional, textural, and sensory properties of Iranian Yazdi cupcake enriched with spirulina (arthrospira platensis)," in Proceedings of the International Conference on Latest Trends in Food, Biological \& Ecological Sciences, Dobai, UAE, October 2015.

[12] N. Zanganeh, H. Barzegar, B. Alizadeh Behbahani, and M. A. Mehrnia, "Investigation of the effect of different Spirulina platensis levels on nutritional, physicochemical and sensory properties of sponge cake," Iranian Food Science and Technology Research Journal, vol. 16, pp. 207-220, 2020.

[13] M. A. Hesarinejad, F. Rezaiyan Attar, O. Mosaffa, and B. Shokrollahi Yancheshmeh, "The effect of incorporation of Chlorella vulgaris into cake as an egg white substitute on physical and sensory properties," Food Science and Technology, vol. 68, pp. 61-72, 2017.

[14] Y. Moradi, A. A. Mattlebi, M. Ghaeni, H. Hadaegh, M. Mosadegh, and K. Khosravi, Investigation on Possibility of Enrichment Some Grain Products (Bread, Cup Cake and Cookie by Using Spirulina Microalga, pp. 1-41, Ministry of Jihad-e-Agriculture Agricultural Research, Education and Extension Organization Iranian Fisheries Science Research Institute, Iran, 2016.

[15] R. Massoud, K. Khosravi-Darani, F. Nakhsaz, and L. Varga, "Evaluation of physicochemical, microbiological and sensory properties of Croissants fortified with arthrospira platensis (spirulina). Food technology and economy, engineering and physical properties Czech," Journal of Food Science, vol. 34, no. 4, pp. 350-355, 2016.

[16] K. Khosravi-Darani, Z. Gholami, and L. Gouveia, "Effect of arthrospira platensis on the shelf life, sensorial and rheological properties of strudel," Romanian Biotechnology Letters, vol. 22, no. 1, pp. 12250-12258, 2017.

[17] N. Stejskal, J. M. Miranda, J. F. Martucci, R. A. Ruseckaite, J. Barros-Velázquez, and S. P. Aubourg, "Quality enhancement of refrigerated Hake muscle by active packaging with a protein concentrate from spirulina platensis," Food and Bioprocess Technology, vol. 13, no. 7, pp. 1110-1118, 2020.

[18] M. Sáez, M. D. Suárez, F. J. Alarcón, and T. F. Martínez, "Assessing the potential of algae extracts for extending the shelf life of rainbow trout (Oncorhynchus mykiss) fillets," Foods, vol. 10, Article ID 910, 2021.

[19] M. B. Taghavi Takyar, S. Haghighat Khajavi, and R. Safari, "Evaluation of antioxidant properties of Chlorella vulgaris and Spirulina platensis and their application in order to extend the shelf life of rainbow trout (Oncorhynchus mykiss) fillets during refrigerated storage," Lebensmittel-Wissenschaft \& Technologie, vol. 100, pp. 244-249, 2019.

[20] ISIRI, Fruit Paste- Specifications and Test Methods, Iranian National Standardization Organization, Tehran, Iran, 2nd edition, 2018.

[21] ISIRI, Processed Fruit - Specifications and Test Methods, Iranian National Standardization Organization, Tehran, Iran, 2nd edition, 2019.

[22] T. Assadi, A. Bargahi, G. H. Mohebbi et al., "Determination of oil and fatty acids concentration in seeds of coastal halophytic Sueada aegyptica plant," Iranian South Medical Journal, vol. 16, no. 1, pp. 9-16, 2013.

[23] D. M. El Maghraby and E. M. Fakhry, "Lipid content and fatty acid composition of Mediterranean macro-algae as dynamic factors for biodiesel production," Oceanologia, vol. 57, no. 1, pp. 86-92, 2015.

[24] B. Tavazzi, G. Lazzarino, D. Di-Pierro, and B. Giardina, "Malondialdehyde production and ascorbate decrease are associated to the reperfusion of the isolated postischemic rat heart," Free Radical Biology and Medicine, vol. 13, no. 1, pp. 75-78, 1992.

[25] B. Faye, S. K. Saleh, G. Konuspayeva, A. Musaad, M. Bengoumi, and R. Seboussi, "Comparative effect of organic and inorganic selenium supplementation on selenium status in camel," Journal of King Saud University Science, vol. 26, no. 2, pp. 149-158, 2014.

[26] J. Mirazimi, M. Dehghanzadeh, and S. Shahrani, ICP-MS \& OES, Materials Characterization, First group, Aberdeen, UK, 2013.

[27] B. Darcy-Vrillon, "Nutritional aspects of the developing use of marine macroalgae for the human food industry," 
International Journal of Food Sciences \& Nutrition, vol. 44, pp. 23-35, 1993.

[28] D. I. Sánchez-Machado, J. López-Cervantes, J. LópezHernández, and P. Paseiro-Losada, "Fatty acids, total lipid, protein and ash contents of processed edible seaweeds," Food Chemistry, vol. 85, no. 3, pp. 439-444, 2004.

[29] J. Finley and F. Shahidi, "The chemistry, processing, and health benefits of highly unsaturated fatty acids: an overview," ACS Symposium Series, Chapter 1, American Chemical Society, Washington, DC, WA, USA, American Chemical Society, 2001 .

[30] D. L. Alonso and F. G. Maroto, "Plants as 'chemical factories' for the production of polyunsaturated fatty acids," Biotechnology Advances, vol. 18, no. 6, pp. 481-497, 2000.

[31] M. B. New and U. N. Wijkström, Use of Fishmeal and Fish Oil in Aqua Feeds: Further Thoughts on the Fishmeal Trap, FAO, Rome, Italy, 2002.

[32] L. Gouveia, A. P. Batista, A. Raymundo, and N. Bandarra, "Spirulina maximaandDiacronema vlkianummicroalgae in vegetable gelled desserts," Nutrition \& Food Science, vol. 38, no. 5, pp. 492-501, 2008.

[33] M. J. Zibaee-Nezhad, M. Khosravi, and N. Baniasadi, "Omega-3 fatty acid content in various tissues of different Persian Gulf fish," International Cardiovascular Research Journal, vol. 2, no. 1, pp. 24-31, 2008.

[34] B. J. Gosch, M. Magnusson, N. A. Paul, and R. De Nys, "Total lipid and fatty acid composition of seaweeds for the selection of species for oil-based biofuel and bioproducts," GCB Bioenergy, vol. 4, no. 6, pp. 919-930, 2012.

[35] H. M. Khairy and S. M. El-Shafay, "Seasonal variations in the biochemical composition of some common seaweed species from the coast of Abu Qir Bay, Alexandria, Egypt," Oceanologia, vol. 55, no. 2, pp. 435-452, 2013.

[36] E. H. Belarbi, E. Molina, and Y. Chisti, "A process for high yield and scaleable recovery of high purity eicosapentaenoic acid esters from microalgae and fish oil," Enzyme and Microbial Technology, vol. 26, no. 7, pp. 516-529, 2000.

[37] Y. Chisti, "Biodiesel from microalgae," Biotechnology Advances, vol. 25, no. 3, pp. 294-306, 2007.

[38] K. Rohani-Ghadikolaei, E. Abdulalian, and W.-K. Ng, "Evaluation of the proximate, fatty acid and mineral composition of representative green, brown and red seaweeds from the Persian Gulf of Iran as potential food and feed resources," Journal of Food Science \& Technology, vol. 49, no. 6, pp. 774-780, 2012.

[39] S. A. Banamoon, "Fatty acids in marine macroalgae from Southern Yemen (Hadramout) including occurrence of eicosatetraenoic (20: 4) and eicosapentaenoic (20: 5) acids," Botanica Marina, vol. 35, no. 2, pp. 165-168, 1992.

[40] M. Tabarsa, M. Rezaei, Z. Ramezanpour, J. Robert Waaland, and R. Rabiei, "Fatty acids, amino acids, mineral contents, and proximate composition of some Brown Seaweeds1," Journal of Phycology, vol. 48, no. 2, pp. 285-292, 2012.

[41] H. Pereira, L. Barreira, F. Figueiredo et al., "Polyunsaturated fatty acids of marine macroalgae: potential for nutritional and pharmaceutical applications," Marine Drugs, vol. 10, no. 9, pp. 1920-1935, 2012.

[42] A. P. Muralidhar, K. Syamala, and C. Prakash, "Comparative studies of fatty acid composition of three marine macroalgae collected from Mandapam region: south east coast of India," World Applied Sciences Journal, vol. 11, no. 8, pp. 958-965, 2010.
[43] M. Orders, S. E. Duncan, and K. M. Waterman, "Sensory evaluation of mozzarella cheese supplemented with algal oil," IRB Infrastructure, vol. 8, Article ID 157, 2008.

[44] K. Ito and K. Hori, "Seaweed: chemical composition and potential food uses," Food Reviews International, vol. 5, no. 1, pp. 101-144, 1989.

[45] L. E. Cruz-Suarez and M. Tapia-Salazar, "Harina de Kelp. En Manual de Ingredients porticos aditivos empleados en la formulacion de alimentos balanceados para camarones peneidos," in Humberto Villarreal Colmenares $Y$ Jorge L. Fenucci, T. Garcia Galano, Ed., pp. 50-61, Universidad Autonoma de Nuevo Leon, Monterrey, Nuevo Leon, Mexico, 2007.

[46] L. E. Cruz-Suarez, M. Tapia-Salazar, M. G. Nieto-Lopez, C. Guajardo-Barbosa, and D. Ricque-Marie, "Comparison of Ulva clathrata and the Kelps Macrocystis pyrifera and ascophyllum nodosum as ingradients in shrimp feeds," Aquaculture Nutrition, vol. 15, no. 4, 2008.

[47] K. H. Wong and P. C. K. Cheung, "Nutritional evaluation of some subtropical red and green seaweeds," Food Chemistry, vol. 71, no. 4, pp. 475-482, 2000.

[48] B. Branger, J. L. Cadudal, M. Delobel et al., C. Personnels and P. Ancel, La spiruline comme complément alimentaire dans la malnutrition du nourrisson au Burkina-Faso," Archives de Pediatrie, vol. 10, no. 5, pp. 424-431, 2003.

[49] G. Z. De Caire, J. L. Parada, M. C. Zaccaro, and M. M. S. de Cano, "Effect of Spirulina platensis biomass on the growth of lactic acid bacteria in milk," World Journal of Microbiology and Biotechnology, vol. 16, no. 6, pp. 563-565, 2000.

[50] S. Mazinani, V. Fadaei, and K. Khosravi-Darani, "Impact ofSpirulina platensison physicochemical properties and viability of Lactobacillus acidophilus of probiotic UF feta cheese," Journal of Food Processing and Preservation, vol. 40, no. 6, pp. 1318-1324, 2016.

[51] A. Bocanegra, S. Bastida, J. Benedí, S. Ródenas, and F. J. Sánchez-Muniz, "Characteristics and nutritional and cardiovascular-health properties of seaweeds," Journal of Medicinal Food, vol. 12, no. 2, pp. 236-258, 2009. 